Süleyman Demirel Üniversitesi Fen Edebiyat Fakültesi Fen Dergisi

Süleyman Demirel University Faculty of Arts and Sciences Journal of Science

2021, 16(1): 216-224

DOI: $10.29233 /$ sdufeffd.891066

Atıf için / For Citation: B.Esencan Turkaslan, "The Effect of Environmental and Chemical

Approach on rGO Structure", Süleyman Demirel Üniversitesi Fen Edebiyat Fakültesi Fen

Dergisi, 16(1), 216-224, 2021

\title{
The Effect of Environmental and Chemical Approach on rGO Structure
}

\author{
Banu ESENCAN TURKASLAN ${ }^{* 1}$ \\ ${ }^{1}$ Suleyman Demirel University, Faculty of Engineering, Department of Chemical Engineering, 32260, \\ Isparta, Turkey \\ *corresponding author: banuturkaslan@sdu.edu.tr
}

(Alınış / Received: 04.03.2021, Kabul / Accepted: 05.05.2021, Yayımlanma / Published: 27.05.2021)

\begin{abstract}
Reduced graphene oxide (rGO) and graphene oxide (GO) are gaining popularity among many research areas. rGO synthesis is based on bottom-up production, which consists of two different stages: the oxidation of graphite and the reduction of GO. The properties of rGO structure are determined by GO used as raw material, reducing agents and the type of process. Different chemical agents are used to reduce GO to rGO and among these, hydrazine is known to be the strongest and effective, but the most toxic agent.

In this study, the rGO structure synthesized using sulfur-containing sodium dithionite $\left(\mathrm{Na}_{2} \mathrm{~S}_{2} \mathrm{O}_{4}\right)$ was compared with the rGO structure synthesized by L-ascorbic acid (Vitamin C) agent in terms of layer number, elemental analysis and crystal structures, and It has been observed that $\mathrm{Na}_{2} \mathrm{~S}_{2} \mathrm{O}_{4}$ may be a good is a good alternative. to reduce GO. GO was synthesized by Modified Improved Hummers method without using toxic sodium nitrate. The reduced products were examined by FTIR, XRD and SEM/EDS. Results showed that different reducing agents synthesized similar rGO- $\mathrm{Na}_{2} \mathrm{~S}_{2} \mathrm{O}_{4}$ and rGO-LAA structures with $0.34 \mathrm{~nm}$ interlayer space also they included \% 14.27 and \%12.24 of oxygen respectively.
\end{abstract}

Key words: Reduced graphene oxide, Graphene oxide, Ascorbic acid, Sodium dithionite, Modified improved hummers

\section{Çevresel ve Kimyasal Yaklaşımın rGO Yapısına Etkisi}

Özet: İndirgenmiş grafen oksit (rGO) ve grafen oksit (GO) birçok araştırma alanında popülerlik kazanmaktadır. rGO sentezi, grafitin oksidasyonu ve GO'nun indirgenmesi olmak üzere iki faklı aşamadan oluşan aşă̆ıdan yukarı üretim esasına dayanır. rGO yapısının özelliklerini, hammadde olarak kullanılan GO, indirgeme ajanları ve proses türü belirlemektedir. GO'yu rGO'ya indirgemek için farklı kimyasal ajanlar kullanılır ve bunlar arasında hidrazinin en güçlü ve etkili ancak en toksik ajan olduğu bilinmektedir.

$\mathrm{Bu}$ çalışmada, kükürt içeren sodyum ditiyonit $\left(\mathrm{Na}_{2} \mathrm{~S}_{2} \mathrm{O}_{4}\right)$ kullanılarak sentezlenen rGO yapısını, katman sayısı, elementel analiz ve kristal yapılar açısından L-askorbik asit (Vitamin C) ajanı ile sentezlenen rGO yapısı ile karşılaştırılmış ve $\mathrm{Na}_{2} \mathrm{~S}_{2} \mathrm{O}_{4}$ 'ün GO'nun indirgenmesi için iyi bir alternatif olabileceği görülmüştür. GO, toksik sodyum nitrat kullanılmadan Modifiye İyileştirilmiş Hummers Yöntemi ile sentezlenmiştir. İndirgenen ürünler, FTIR, XRD ve SEM / EDS ile incelenmiştir. Sonuçlar, farklı indirgeyici ajanların, $0.34 \mathrm{~nm}$ tabakalar arası mesafeye sahip benzer rGO-Na $\mathrm{S}_{2} \mathrm{O}_{4}$ ve rGO-LAA yapılarının sentezlediğini ayrıca bu yapıların sirasıyla $\% 14.27$ ve $\% 12.24$ oksijen içerdiğini göstermiştir.

Banu ESENCAN TÜRKASLAN, banuturkaslan@sdu.edu.tr, ORCID: https://orcid.org/0000-0003-39486207 
Anahtar kelimeler: İndirgenmiş grafen oksit, Grafen oksit, Askorbik asit, Sodyum ditiyonit, Modifiye geliştirilmiş hummers 


\section{Introduction}

Graphene is a two-dimensional (2D) nanomaterial in which carbon atoms are arranged in a crystal lattice. [1]. It is used in advanced material study in various technological and biomedical applications with its extraordinary properties. However low solubility in solution resulting in agglomeration led to the search for alternative materials with similar structures [2,3]. Reduced graphene oxide (rGO) and graphene oxide (GO) are considered to be a graphene derivative with outstanding properties especially mechanical and electrical [4-9].

GO is reacted with different agents to decrease the number oxygen groups and reach similar structure of functionalized graphene called rGO [10]. Therefore, it is very important to find a suitable reducing agent to obtain $\mathrm{rGO}$ with the desired properties.

The first agent used for the reduction process is hydrogen sulfide. In recent years, hydrazine/ hydrazine derivatives, which are strong reducing agents in terms of reaction time and efficiency, are more preferred [11]. Also sodium dithionite $\left(\mathrm{Na}_{2} \mathrm{~S}_{2} \mathrm{O}_{4}\right)$ is a strong reducing agent that is slowly hydrolyzed by water. Generally $\mathrm{Na}_{2} \mathrm{~S}_{2} \mathrm{O}_{4}$ is preferred as the main reducing agent in the removal of harmful compounds from waste water and in textile applications. Dogan used $\mathrm{Na}_{2} \mathrm{~S}_{2} \mathrm{O}_{4}$ and sodium borohydride $\left(\mathrm{NaBH}_{4}\right)$ as a reduced agent, for the reduction of $\mathrm{GO}$ coated polyester fabrics. They determined that polyester fabrics reduced with $\mathrm{Na}_{2} \mathrm{~S}_{2} \mathrm{O}_{4}$ showed more successful conductivity values than $\mathrm{NaBH}_{4}$ [12].

As a result of the toxic nature of hydrazine, a number of alternatives such as organic acids [13-16], amino acids [17,18], microorganisms [19], sugars [20] have been originated. Ascorbic acid $\left(\mathrm{C}_{6} \mathrm{H}_{8} \mathrm{O}_{6}\right)$ is a non-toxic and high reducing potential agent which used for the reduction of GO. In addition to being an environmental friendly and inexpensive agent, it creates more stable rGO products than hydrazine. [21].

A study comparing the reduction capacities of hydrazine, sodium borohydride and LAA agents was performed by Fernandez-Merino et al. [22]. They showed that only LAA can compete with hydrazine in terms of reduction efficiency. Moreover they were able to form stable suspensions of rGO-LAA structures both in water and organic solvents. Chen et al. [23] used sulfur-containing agents such as $\mathrm{NaHSO}_{3}, \mathrm{Na}_{2} \mathrm{SO}_{3}$, $\mathrm{Na}_{2} \mathrm{~S}_{2} \mathrm{O}_{3}$ to reduce GO. Among them, $\mathrm{NaHSO}_{3}$ is the least toxic, and the electrical conductivity of rGO prepared using $\mathrm{NaHSO}_{3}$ was calculated as $6500 \mathrm{~S} \mathrm{~m}^{-1}$, whereas for hydrazine reduced GO was found to be $5100 \mathrm{~S} \mathrm{~m}^{-1}$.

The goal of this study is to reduce GO by different agent to rGO. L-AA and its chemical counterpart $\mathrm{Na}_{2} \mathrm{~S}_{2} \mathrm{O}_{4}$, were selected as a green and chemical reduced agents respectively. During GO synthesis, based on less chemicals and quantities was carried out using the "Modified Improved Hummers" method we developed in our previous study [24].

\section{Material and Method}

\subsection{Material}


Graphite (99\%), hydrochloric acid (HCI-\%37), potassium permanganate $\left(\mathrm{KMnO}_{4}\right.$ \%99), hydrogen peroxide $\left(\mathrm{H}_{2} \mathrm{O}_{2}, \% 30\right)$, sulfuric acid $\left(\mathrm{H}_{2} \mathrm{SO}_{4}-\% 98\right)$, L-AA and $\mathrm{Na}_{2} \mathrm{~S}_{2} \mathrm{O}_{4}$, $(\% 99,80)$ from Sigma Aldrich.

\subsection{Synthesis of $G O$ and $r G O$}

Flake graphite powders was added to $50 \mathrm{~mL} \mathrm{H}_{2} \mathrm{SO}_{4}$ and stirred for $2 \mathrm{~h} .6 \mathrm{~g} \mathrm{KMnO} 4$ was added in three equal parts to the mixture in a water bath while keeping the temperature at less than $40^{\circ} \mathrm{C}$. The resulting solution was diluted by adding $300 \mathrm{~mL}$ of water then the temperature was raised to $90^{\circ} \mathrm{C}$ and stirring was continued. Then $2 \mathrm{~mL} \mathrm{H}_{2} \mathrm{O}_{2}$ was added and a bright yellow color was obtained. The resulting graphite oxide was washed and filtered to remove impurities with $\mathrm{HCl}$ and deiyonized water (DI) respectively. The GO nanosheets were obtained by centrifugated for 40 minutes at $7000 \mathrm{rpm}$ and 10 minutes at $9000 \mathrm{rpm}$.

L-AA $(100 \mathrm{mg})$ was added to the aqueous dispersion of $100 \mathrm{~mL}\left(0.1 \mathrm{mg} \mathrm{mL}^{-1}\right) \mathrm{GO}$. The $\mathrm{pH}$ was adjusted to 10 by adding $\mathrm{NH}_{3}$ solution. The mixture was stirred at $90^{\circ} \mathrm{C}$ for 2 hours. The resulting rGO-LAA was filtered, washed and dried for 24 hours. Similar to rGO-LAA, $1.2 \mathrm{~g}$ of $\mathrm{Na}_{2} \mathrm{~S}_{2} \mathrm{O}_{4}$ was added to $160 \mathrm{~mL}\left(0.1 \mathrm{mg} \mathrm{mL}^{-1}\right)$ GO solution with stirring. The $\mathrm{pH}$ was fixed between $9-10$ by adding NH3 solution. The mixture was refluxed at $90^{\circ} \mathrm{C}$ for 12 hours. The resulting rGO-Na $\mathrm{S}_{2} \mathrm{O}_{4}$ was filtered, washed and dried for $24 \mathrm{~h}$.

\section{Results}

\subsection{Determination of graphite oxidation}

Figure 1 shows XRD patterns for GO indicates graphite is oxidized. Because of the intercalation of functional groups between graphite layers interlayer space increased to $0.81 \mathrm{~nm}$ which belongs to GO located at about $2 \Theta=11.5 \mathrm{~nm}[25]$.

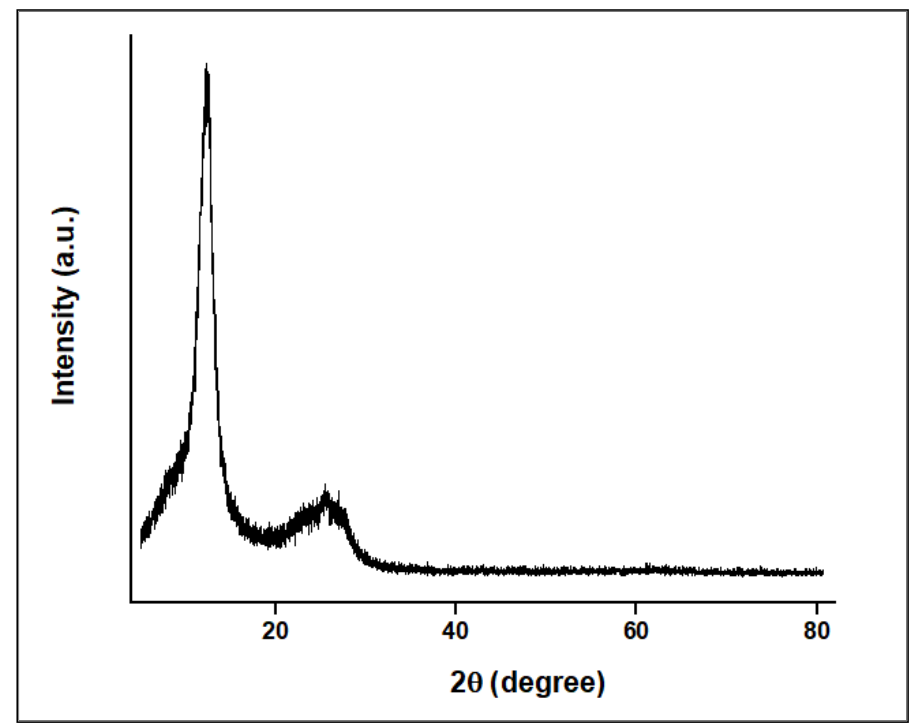

Figure 1. XRD pattern of GO

Figure 2 shows the morphological changes of graphite during the oxidation to GO. As can be seen in EDS analyzes, functional groups added between layers as a result of oxidation of graphite form the layered GO morphology (Figure $2 \mathrm{a}-\mathrm{b}$ ) [26]. 


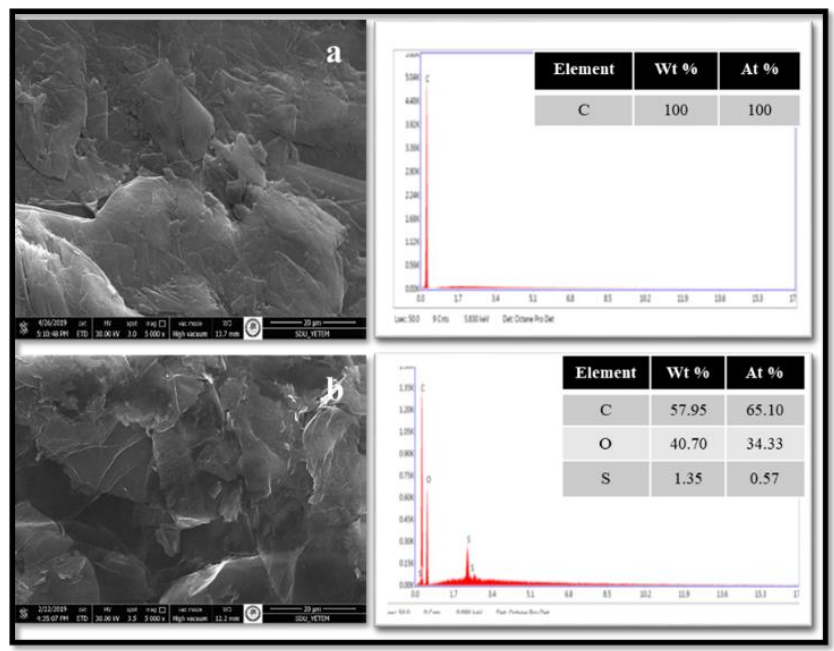

Figure 2. SEM/EDX image of graphite (a) and GO (b)

\section{2. $r G O$ results}

As shown in XRD pattern after reduction due to removal of oxygen functional groups from $\mathrm{rGO}-\mathrm{Na}_{2} \mathrm{~S}_{2} \mathrm{O}_{4}$ and rGO-LAA the interlayer spacing again decreases and peaks shifted to nearly $2 \mathrm{O}=26.5^{\circ}$ (d-spacing: $0.34 \mathrm{~nm}$ ) [27]. XRD pattern of $\mathrm{rGO}-\mathrm{Na}_{2} \mathrm{~S}_{2} \mathrm{O}_{4}$ exhibits second peaks which might be due to residues of the reduction process.

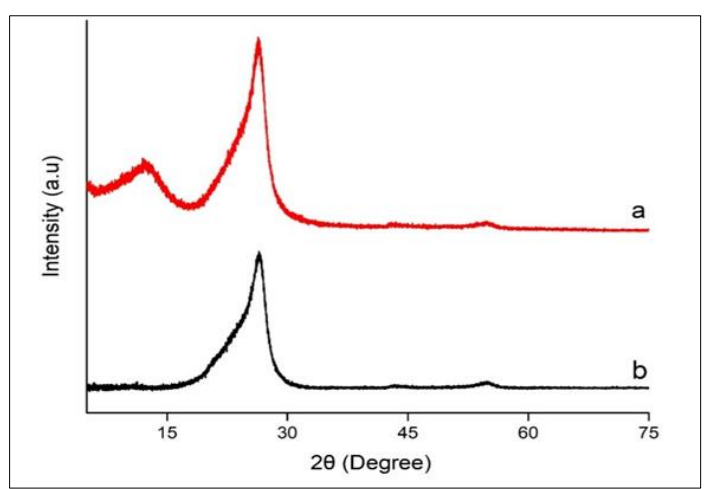

Figure 3. XRD patterns of $\mathrm{rGO}-\mathrm{Na}_{2} \mathrm{~S}_{2} \mathrm{O}_{4}$ (a) and $\mathrm{rGO}-\mathrm{LAA}$ (b)

The number of layers for rGO from XRD spectroscopy can be calculated by the ratio of crystal size (tc) to interlayer distance (d) [28]. It is seen in Table 1 that the layer numbers of the obtained rGO structures are very close to each other.

Table 1. Peak position and d-spacing of rGO structures

\begin{tabular}{|c|c|c|c|}
\hline Sample & $\mathbf{t}_{\mathrm{c}}(\mathrm{nm})$ & d (nm) & $\begin{array}{c}\text { Number of } \\
\text { Layers }\end{array}$ \\
\hline $\mathrm{rGO}-\mathrm{Na}_{2} \mathrm{~S}_{2} \mathrm{O}_{4}$ & 3.14 & 0.34 & 9.23 \\
\hline rGO-LAA & 3 & 0.34 & 8.82 \\
\hline
\end{tabular}


Figure 4 shows the morphological differences of varying reducing agents on the synthesized $\mathrm{rGO}-\mathrm{Na}_{2} \mathrm{~S}_{2} \mathrm{O}_{4}$ and $\mathrm{rGO}-\mathrm{LAA}$ structures.
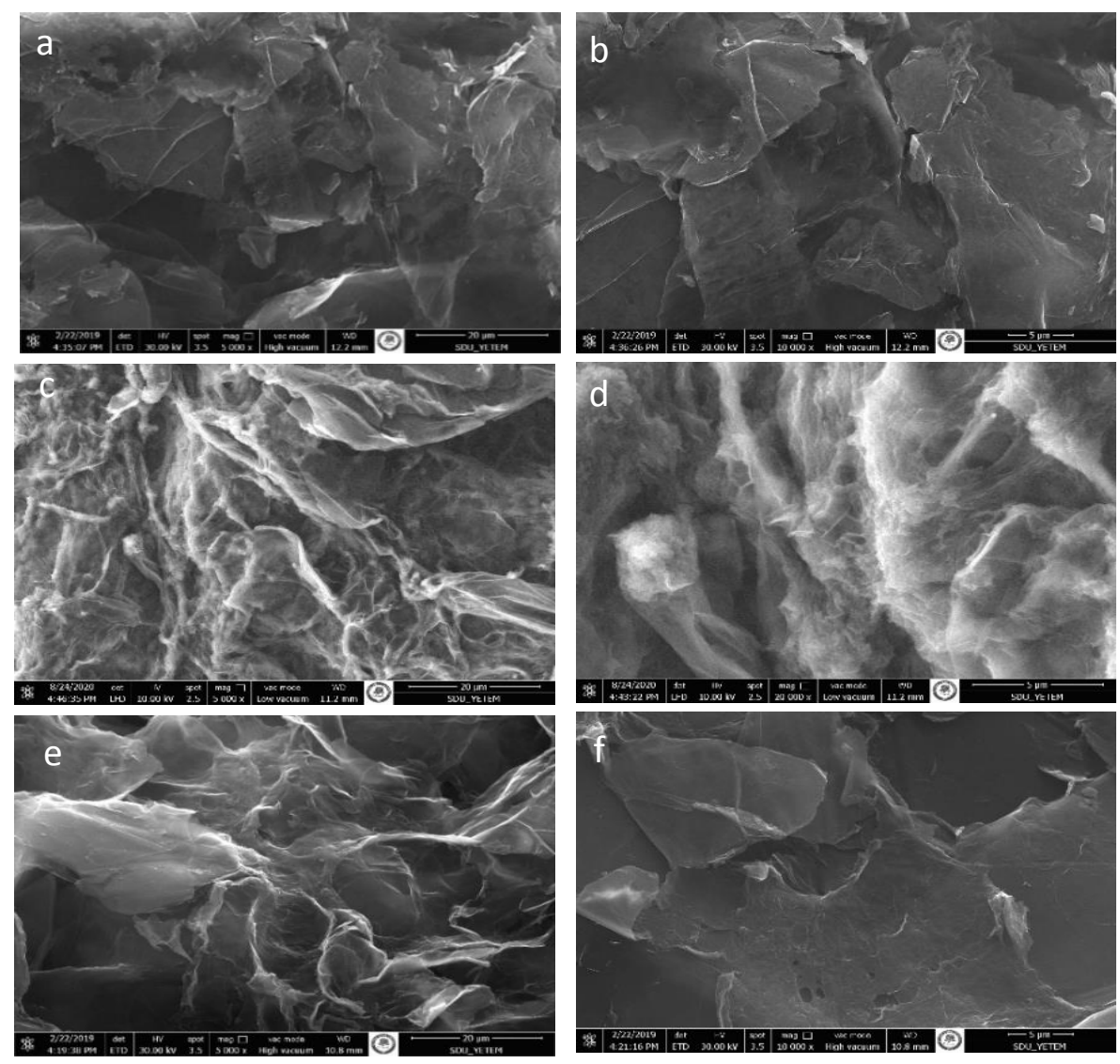

Figure 4. SEM image of GO (a,b), rGO- $\mathrm{Na}_{2} \mathrm{~S}_{2} \mathrm{O}_{4}(\mathrm{c}, \mathrm{d})$ and rGO-LAA (e,f)

After the GO reduced layered and wavy edges (Figure 4 a -b) morphology has been disappeared. Figure 4 e-f showed that rGO-LAA is a well expanded and exfoliated thin transparent sheet structure while $\mathrm{rGO}-\mathrm{Na}_{2} \mathrm{~S}_{2} \mathrm{O}_{4}$ compact and stacked morphology (Figure 4c-d). Compared to rGO-LAA, residues of the reduction process resulted in the formation of different elements in the rGO- $\mathrm{Na}_{2} \mathrm{~S}_{2} \mathrm{O}_{4}$ structure. It is also seen from the EDS (Table 2) that the quantity of functional oxygen in the rGO-LAA structure is removed more than the $\mathrm{rGO}-\mathrm{Na}_{2} \mathrm{~S}_{2} \mathrm{O}_{4}$ structure.

Table 2. Chemical composition of GO, rGO- $\mathrm{Na}_{2} \mathrm{~S}_{2} \mathrm{O}_{4}$ and rGO-LAA obtained from EDS analysis

\begin{tabular}{ccccc}
\hline Sample & \multicolumn{4}{c}{ Elemental Composition (at\%) } \\
\hline $\mathrm{GO}$ & $\mathrm{C}$ & $\mathrm{O}$ & $\mathrm{S}$ & $\mathrm{Na}$ \\
$\mathrm{rGO}-\mathrm{Na}_{2} \mathrm{~S}_{2} \mathrm{O}_{4}$ & 57.95 & 40.70 & 1.34 & - \\
$\mathrm{rGO}-\mathrm{LAA}$ & 84.11 & 14.27 & 0.90 & 15.65 \\
\hline
\end{tabular}


FTIR spectra of $\mathrm{rGO}-\mathrm{Na}_{2} \mathrm{~S}_{2} \mathrm{O}_{4}$ and $\mathrm{rGO}-\mathrm{LAA}$ in Figure 5 displays the distinctive peaks at $3442 \mathrm{~cm}^{-1}, 3446 \mathrm{~cm}^{-1}(\mathrm{O}-\mathrm{H}), 1702 \mathrm{~cm}^{-1}, 1741 \mathrm{~cm}^{-1}(\mathrm{C}=\mathrm{O}), 1645 \mathrm{~cm}^{-1}, 1638 \mathrm{~cm}^{-1}$ $(\mathrm{C}=\mathrm{C})$ and $\mathrm{C}-\mathrm{O}$ band within the range of $1059 \mathrm{~cm}^{-1}$ respectively [29].

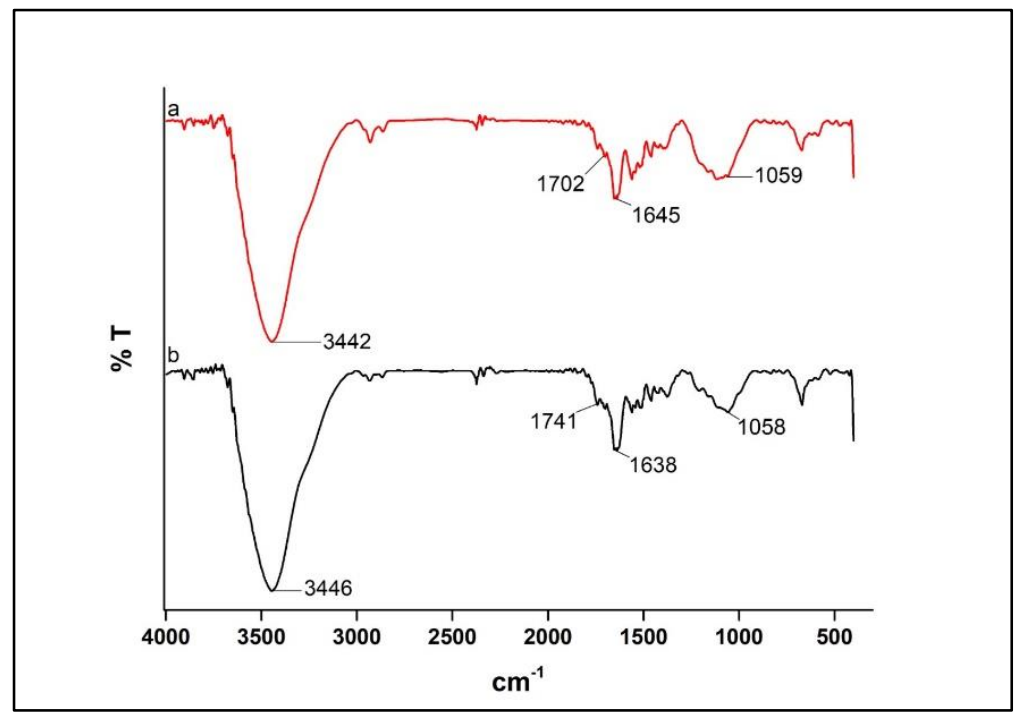

Figure 5. FTIR spectrum of (a) rGO-LAA and (b) $\mathrm{rGO}_{-} \mathrm{Na}_{2} \mathrm{~S}_{2} \mathrm{O}_{4}$

\section{Conclusion and Comment}

GO was reduced using L-AA and $\mathrm{Na}_{2} \mathrm{~S}_{2} \mathrm{O}_{4}$ agents and produces similar structures. Possible reduction mechanisms of GO by $\mathrm{Na}_{2} \mathrm{~S}_{2} \mathrm{O}_{4}$ agent, $\mathrm{S}_{2} \mathrm{O}_{4}{ }^{-2}$ attacked the hydroxyl groups on GO then $\mathrm{S}_{2} \mathrm{O}_{4}^{-2}$ was oxidized to $\mathrm{SO}_{3}{ }^{-2}$ to result in the GO is reduced to rGO. L-AA increased the acidity of the hydroxyl groups and attached on the epoxide and diol groups to create dehydroascorbic acid meanwhile GO reduced to rGO. By optimizing the experimental conditions of green and chemical approaches, we examined the possible effects of different reduced agents on the characterization of the rGO structures and the differences between them. The XRD and SEM/EDS showed oxidation of graphite to $\mathrm{GO}$ and there were no $\mathrm{Mn}^{+}$ions and other impurities in its structure.

After reduction according to the XRD spectrum the characteristic structure of rGO coexist in the rGO- $\mathrm{Na}_{2} \mathrm{~S}_{2} \mathrm{O}_{4}$ and rGO-LAA. In addition rGO-Na $\mathrm{Na}_{2} \mathrm{O}_{4}$ has exhibits second peaks which might be due to residues of the reduction process. During the reduction due to the degradation of functional groups, GO structure which consists of 14 layers has been transformed into 9 layer rGO-Na ${ }_{2} \mathrm{~S}_{2} \mathrm{O}_{4} /$ rGO-LAA structure. It was observed that the SEM images of rGO structures and their elemental analysis differ from each other. The decrease in $\mathrm{GO}$ weight and the increase $\mathrm{C} / \mathrm{O}$ ratio indicate that the functional groups in the GO structure are removed by the reduction processes. Hence, we conclude that $\mathrm{Na}_{2} \mathrm{~S}_{2} \mathrm{O}_{4}$ should be accepted as a reducing agent for GO as it is not explosive and is less toxic than hydrazine.

\section{Author Statement}

Banu Esencan Turkaslan: Investigation/ Material/ Instrument Supply/ Formal Analysis/ Original Draft writing/ Review and Editing 


\section{Acknowledgement}

As the authors of this study, we declare that we do not have any support and thank you statement.

\section{Conflict of Interest}

As the author of this study, I declare that I do not have any conflict of interest statement.

\section{Ethics Committee Approval and Informed Consent}

As the author of this study, I declare that I do not have any ethics committee approval and/or informed consent statement.

\section{References}

[1] W. Xiluan, G. Shi, "Introduction to the chemistry of graphene," Phys. Chem. Chem. Phys., 17, 28484-28504, 2015.

[2] R. Kumar, R.K. Singh, D.P. Singh, E. Joanni, R.M. Yadav, S.A. Moshkalev, "Laser-assisted synthesis, reduction and micro-patterning of graphene: Recent progress and applications," Coord. Chem. Rev., 342, 34-79, 2017.

[3] G.V. Dubacheva, C.K Liang, D.M. Bassani, "Functional monolayers from carbon nanostructures - fullerenes, carbon nanotubes, and graphene - as novel materials for solar energy conversion," Coord. Chem. Rev., 256 (21-22), 2628-2639, 2012.

[4] D.P. Singh, C.E. Herrera, B. Singh, S. Singh, R.K. Singh, R. Kumar, "Graphene oxide: An efficient material and recent approach for biotechnological and biomedical applications," Mater. Sci. and Eng.: C, 86, 173-197, 2018.

[5] S.C. Ray, Applications of Graphene and Graphene-Oxide Based Nanomaterials. South Africa: Elsevier, 2015, ch. 2.

[6] A.T. Smith, A.M. LaChance, S. Zeng, B. Liu, L. Sun, "Synthesis, properties, and applications of graphene oxide/reduced graphene oxide and their nanocomposites," Nano Mater. Sci., 1 (1), 3147, 2019.

[7] Y. Zhu, S. Murali, W. Cai, X. Li, J.W. Suk, J.R. Potts, R.S. Ruoff, "Graphene and graphene oxide: Synthesis, properties, and applications,” Advanced Mat., 22 (35), 3906-3924, 2010.

[8] L. Chen, N. Li, M. Zhang, P. Li, Z. Lin, "Effect of preparation methods on dispersion stability and electrochemical performance of graphene sheets," Journal of Solid State Chem., 249, 9-14, 2017.

[9] M.S. Samuel, J. Bhattacharya, S. Raj, N. Santhanam, H. Singh, N.D.P. Singh, "Efficient removal of chromium(VI) from aqueous solution using chitosan grafted graphene oxide (CS-GO) nanocomposite," International Journal of Biological Macromolecules, 121, 285-292, 2019.

[10] G. Eda, M. Chhowalla, "Chemically derived graphene oxide: Towards large-area thin-film electronics and optoelectronics," Advanced Materials, 22 (22), 2392-415, 2010.

[11]V.C. Tung, M.J. Allen, Y. Yang, R.B. Kaner, "High-throughput solution processing of largescale graphene," Nature Nanotechnology, 4, 25-29, 2009.

[12]B. Doğan, "Grafen oksit esaslı multifonksiyonel polyester tekstil ürünlerinin geliştirilmesi," Yüksek Lisans Tezi, Tekstil Mühendisliği, Süleyman Demirel Üniv., Isparta, Türkiye, 2020.

[13] J. Zhang, H. Yang, G. Shen, P. Cheng, J. Zhang, S. Guo, "Reduction of Graphene Oxide Via LAscorbic Acid," Chemical Communic., 46 (7), 1112-1114, 2010. 
[14] W. Wan, Z. Zhao, H. Hu, Y. Gogotsi, J. Qiu, "Highly controllable and green reduction of graphene oxide to flexible graphene film with high strength," Materials Research Bulletin, 48 (11) , 4797-4803, 2013.

[15]Z. Bo, X. Shuai, S. Mao, H. Yang, J. Qian, J. Chen, J. Yan, K. Cen, "Green preparation of reduced graphene oxide for sensing and energy storage applications," Scientific Reports, 4 (4684), 1-8, 2014.

[16] Y. Wang, Z.X. Shi, J. Yin, "Facile synthesis of soluble graphene via a green reduction of graphene oxide in tea solution and its biocomposites," ACS Appl. Mater. and Interfaces, 3 (4), 1127-1133, 2011.

[17] S. Thakur, N. Karak, "Green reduction of graphene oxide by aqueous phytoextracts," Carbon, 50 (14), 5331-5339, 2012.

[18]D. Chen, L. Li, L. Guo, "Environment-friendly preparation of reduced graphene oxide nanosheets via amino acid," Nanotechnology, 22 (32), 1-7, 2011.

[19] G. Wang, F. Qian, C.W. Saltikov, Y. Jiao, Y. Li, "Microbial reduction of graphene oxide by shewanella," Nano Research, 4, 563-570, 2011.

[20] C. Zhu, S. Guo, Y. Fang, S. Dong, "Reducing sugar: New functional molecules for the green synthesis of graphene nanosheets," ACS Nano, 4 (4), 2429-2437, 2010.

[21] K.K.H. De Silva, H.H. Huang, M. Yoshimura, "Progress of reduction of graphene oxide by ascorbic acid," Appl. Surface Sci., 447, 338-346, 2018.

[22] M.J. Fernandez-Merino, L. Guardia, J.I. Parades, S. Villar-Rodil, P. Solis-Fernandez, A. Martinez-Alonso, J.M.D. Tascon, "Vitamin C is an ideal substitute for hydrazine in the reduction of graphene oxide suspensions," The Journal of Physic. Chem. C, 114 (14), 6426-6432, 2010.

[23] W. Chen, L. Yan, P.R. Bangal, "Chemical reduction of graphene oxide to graphene by sulfurcontaining compounds," The Journal of Physical Chemistry C, 114 (47), 19885-19890, 2010.

[24] B. Esencan Türkaslan, M. Filiz Aydın, "Optimizing parameters of graphene derivatives synthesis by modified improved hummers," Mathematical Methods in the Applied Sciences, 1-8, 2020.

[25] C. Li, D. Li, J. Yang, X. Zeng, W. Yuan, "Preparation of single- and few-layer graphene sheets using co deposition on SiC substrate," Journal of Nanomater., 319624, 1-7, 2011.

[26] L. Shahriary, A.A. Athawale, "Graphene oxide synthesized by using modified hummers approach," Intenational Journal Of Renewable Energy And Environmental Engineering, 2 (1), 58-63, 2014.

[27] K. Krishnamoorthy, M. Veerapandian, R. Mohan, S.J. Kim, "Investigation of raman and photoluminescence studies of reduced graphene oxide sheets," Applied Physics A, 106 (3), 501506, 2012.

[28] M. Yazıcı, İ. Tiyek, M.S. Ersoy, M.H. Alma, U. Dönmez, B. Yıldırım, T. Salan, Ş. Karataş, S. Uruş, İ. Karteri, K. Yıldız, "Modifiye hummers yöntemiyle grafen oksit (GO) sentezi ve karakterizasyonu," Gazi Univ. Journal of Science Part: C, 4 (2), 41-48, 2016.

[29]P. Khanra, T. Kuila, N.H. Kim, S.H. Bae, D.S. Yu, J.H. Lee, "Simultaneous biofunctionalization and reduction of graphene oxide by baker's yeast," Chem. Engineer. Journal, $183,526-533,2012$. 